\title{
Social Performance of Indonesian Islamic Banks: The Role of Board of Directors
}

\section{Bima Cinintya Pratama, Amrizah Kamaluddin, Shukriah Saad}

To Link this Article: http://dx.doi.org/10.6007/IJARAFMS/v12-i1/12140 DOI:10.6007/IJARAFMS /v12-i1/12140

Received: 19 December 2021, Revised: 21 January 2022, Accepted: 08 February 2022

Published Online: 24 February 2022

In-Text Citation: (Pratama et al., 2022)

To Cite this Article: Pratama, B. C., Kamaluddin, A., \& Saad, S. (2022). Social Performance of Indonesian Islamic Banks: The Role of Board of Directors. International Journal of Academic Research in Accounting Finance and Management Sciences, 12(1), 201-211.

Copyright: (c) 2022 The Author(s)

Published by Human Resource Management Academic Research Society (www.hrmars.com)

This article is published under the Creative Commons Attribution (CC BY 4.0) license. Anyone may reproduce, distribute, translate and create derivative works of this article (for both commercial and non-commercial purposes), subject to full attribution to the original publication and authors. The full terms of this license may be seen at: http://creativecommons.org/licences/by/4.0/legalcode

Vol. 12, No. 1, 2022, Pg. 201 - 211

Full Terms \& Conditions of access and use can be found at http://hrmars.com/index.php/pages/detail/publication-ethics 


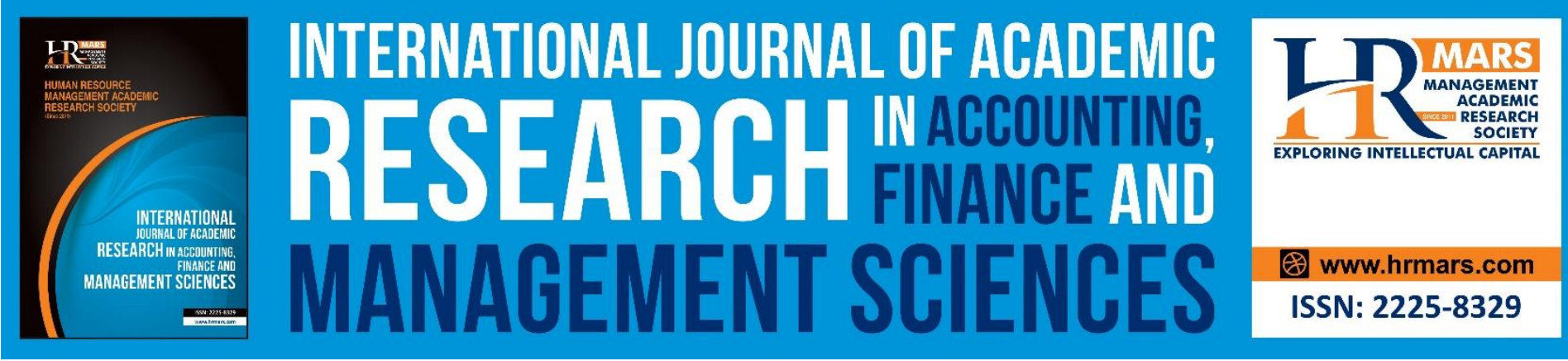

\title{
Social Performance of Indonesian Islamic Banks: The Role of Board of Directors
}

\section{Bima Cinintya Pratama ${ }^{1}$, Amrizah Kamaluddin², Shukriah $\mathrm{Saad}^{3}$}

${ }^{1}$ Faculty of Economics and Business, Universitas Muhammadiyah Purwokerto, Indonesia

2,3 Faculty of Accountancy, Universiti Teknologi MARA, Cawangan, Selangor, Malaysia Corresponding Author Email: BimaCinintyaPratama@ump.ac.id/ pratamabima@gmail.com

\begin{abstract}
This study aims to examine the social performance of Islamic banks by considering Board of Directors as antecedents, because the achievement of social performance is expected to increase the trust and loyalty of depositors, shareholders and other stakeholders towards Islamic banks. Board of Directors variable is proxied by the size of board, board gender diversity, directors' age, and CEO duality. Panel data regression model analysis is used for the sample of Indonesian Islamic banks during 2008-2019 periods. The results showed that the size of board and CEO duality has a positive effect towards Social Performance. Although, the results failed to prove that board gender diversity and directors' age has a positive effect on firm financial performance. It can be concluded that the Board of Directors could manage the social activities conducted by Islamic banks will lead to an improvement of social performance.
\end{abstract}

Keywords: Board of Directors, Social Performance, Islamic Banks

\section{Introduction}

Currently, Islamic banking in Indonesia is growing rapidly. The existence of an interestfree system is one of the reasons that has led to the development of the Islamic banking business. In addition, the government has opened new avenues for Islamic banking through its commitment to form the National Sharia Finance Committee (KNKS). Especially with the launch of the 2019-2024 Islamic Sharia Economic Master Plan. However, in realizing this, the Islamic banking industry still has many challenges to be resolved. Some of these challenges can be faced by Islamic banks as a measure of the performance of the company. The importance of company performance is to measure the smooth management of company resources to generate profits, and capital that can be used to manage its operational activities. Company performance in this study is related to social performance, where basically Islamic banks have a social function that refers to responsibility for the welfare of the community while fulfilling their religious obligations such as zakat, sadaqqa, and qardul hasan (Haniffa \& Hudaib, 2007). The importance of implementing social performance in Islamic banks is because as one of the distinguishing features between Islamic banks and conventional banks, this is because the public will always appreciate Islamic banks as long as 
MANAGEMENT SCIENCES

Vol. 12, No. 1, 2022, E-ISSN: 2225-8329 @ 2022 HRMARS

they can consistently maintain superior ethical and moral values in their activities (Haniffa \& Hudaib, 2007).

Honi et al (2020) defines the board of directors as someone who decides or usually makes decisions, together with other members of the board of directors in determining the necessary actions. Wijethilake et al (2015) stated that the board of directors has a very large contribution in the context of realizing corporate governance. Ntim (2015) add that the board of directors plays a fundamental role in strengthening corporate governance by carrying out an important role in monitoring and advising on the provision of resources. Lipton \& Lorsch (1992); Jensen (1993) limit board membership to a maximum of ten people, with an ideal size of eight or nine. They further argue that although the capacity of board size increases, the benefits are outweighed by slower decision-making, less honest discussion of managerial performance, and can influence risk taking. The results of previous research analysis (Assenga et al., 2018; Muchemwa et al., 2016; Palaniappan, 2017; Topal \& Dogan, 2014) showed a positive relationship between board size and company performance. Negative results were found by (Hermalin \& Weisbach, 2003); Rumapea, 2017). Meanwhile, Honi et al (2020) shows that partially the board of directors has no effect on company performance, which means that many or at least the board of directors does not directly affect the good or bad performance.

The composition of the board of directors is one of the issues related to corporate governance (Amin \& Sunarjanto, 2016). The diversity or diversity in the structure of the board of directors is expected to be an asset that can improve company performance (Innayah et al., 2020, 2021). The gender diversity of the board of directors describes the distribution of men and women who occupy board positions (Anggraeni et al., 2016). The involvement of women on the board of directors shows that there is diversity that can provide benefits for companies such as improving decision making (Carter et al., 2010).

With regard to the composition of members of the board of directors, not only gender is considered to affect company performance, but age is also considered a factor that can affect company performance. The characteristics of the board of directors in terms of age are related to the policies they have, especially the wisdom in making decisions (Zulkarnain \& Mirawati, 2019). The age of the board of directors is considered to be better when it is over 40 years old (Zulkarnain \& Mirawati, 2019).

The last aspect of directors that may affect the company's performance is the concurrent position of the board of directors or CEO duality. The CEO duality can result in the monitoring function of the board of commissioners being less effective because the person concerned has to supervise the board of directors including himself (Putri \& Deviesa, 2017). Then according to Ferris et al (2003) multiple positions on the board of directors can reduce the effectiveness of monitoring activities because directors who have concurrent positions have to oversee more than one company.

Based on the above background, it is important to conduct research on the social performance of Islamic banks by considering Board of Directors as antecedents, since the achievement of social performance is expected to increase the confidence and loyalty of depositors, shareholders and other stakeholders towards Islamic banks. It is hoped that this will assess the performance of Islamic banks in a systematic way by focusing on the social performance of islamic banking.

This research was conducted on sharia banking firms in Indonesia during 2008-2019. The research uses a regression model of the data panel, i.e. fixed effect and random effect 
MANAGEMENT SCIENCES

Vol. 12, No. 1, 2022, E-ISSN: 2225-8329 @ 2022 HRMARS

regression. This research contributes by providing practical implications to the company by focusing on the role of board of directors in enhancing IB's social performance.

\section{Literature Review And Hypothesis Development The Effect of Board Size on Company Performance}

Agency theory explains the function of the board of directors to monitor and control managers. This is based on the agency problem that arises when two parties have different goals. The relationship between the principal and the agent is defined as a contract in which the principal engages the agent in his duties to the principal.

The agency relationship plays the most important role in company performance, and it is based on the composition of the board of directors (Jensen \& Meckling, 1976). The number of boards of directors increases the independence of the board of directors (Carter et al., 2003). A diversified board of directors has a very significant influence on company performance and company value creation. As a result, wealth can be maximized and this increases stakeholder trust and has a positive impact on company performance (Hassan \& Marimuthu, 2016).

Previous research (Assenga et al., 2018; Muchemwa et al., 2016; Ntim, 2015; Palaniappan, 2017; Topal \& Dogan, 2014) on the effect of board size on company performance found that board size has a positive effect on performance. company. Based on this description, the following hypothesis is drawn:

H1: The Board size has a positive effect on the Social Performance of Islamic Banks

\section{The Effect of Gender of Directors on Company Performance}

Gender diversity on the board of directors is believed to be able to affect company performance, both in the short and long term and is able to increase effectiveness in monitoring activities (Amin \& Sunarjanto, 2016). Gender diversity with the presence of a female board of directors will compensate for the role of a man in leading. The view of a man who has a firm, strong, tough attitude will be balanced by a woman who has a prudent attitude, tends to avoid risks, and is more conscientious so that it will result in more precise decision making and a lower risk of mistakes (Amin \& Sunarjanto, 2016). A positive viewpoint about women on the board of directors is possible because women tend to be more resilient and have a higher level of commitment. so as to manage the company better.

The results of this study are in line with what Amin \& Sunarjanto (2016); Rompis et al (2018) have found evidence that the presence of women or gender diversity on the board of directors has a positive influence on company performance. This is because the presence of women has better governance and performance and has a qualified and extraordinary quality of ability (Amin and Sunarjanto, 2016). With this, the third hypothesis is formulated as follows:

$\mathrm{H}$ 2: Gender diversity has a positive effect on the Social Performance of Islamic Banks.

\section{The Effect of Age of Directors on Social Performance}

Age can be an indicator of a person's experience and wisdom, the longer a person lives, the more professional the experience they have. Based on Upper Echelons Theory proposed by Hambrick \& Mason (1984) the demographic characteristics of the top management team such as age, education and experience will influence their decision making. Supported by previous research conducted by Hassan \& Marimuthu (2016) who found empirical evidence that the age of the Board of Directors has a positive effect on social performance. Older leaders who 
MANAGEMENT SCIENCES

Vol. 12, No. 1, 2022, E-ISSN: 2225-8329 @ 2022 HRMARS

have a lot of experience, are full of caution and are reluctant to take risks lead to better company performance. Based on these findings, the hypotheses to be tested are:

H3: Age of the Board of Directors has a Positive Effect on the Social Performance of Islamic Banks.

\section{The Effect of CEO Duality on Company Performance}

CEO duality is a condition in which the board of directors who is in charge of running the company is also a commissioner who has the duty to supervise and evaluate the running of the company. Under these circumstances, multiple positions lead to the absence of separation of control in management decision making, so that the board of commissioners cannot monitor and evaluate the board of directors effectively (Fama \& Jensen, 1983). Because when the two boards are concurrent, the monitoring function carried out by the board of commissioners will be less effective because it has to supervise the board of directors which includes itself (Putri \& Deviesa, 2017).

The results of this study are in line with what was stated by Fama \& Jensen (1983), Putri \& Deviesa (2017), Setyawan \& Devie (2017), Shukeri et al. (2012) which stated that dual leadership has a negative effect on company performance. This is because companies that implement multiple leadership structures tend to have low performance (Putri and Deviesa, 2017). With this, the fourth hypothesis is formulated as follows:

H4: CEO duality of directors have a positive effect on the Social Performance of Islamic Banks

\section{Research Methods}

\section{Sample Selection and Data Sources}

The population and sample used in this study are Islamic commercial banks registered with the Financial Services Authority (OJK) from 2008 to 2019. The data in this study were taken through the official website of the OJK or the company's official website. The data collection method used in this research is documentation with a pooled unbalanced panel, which is to use all available samples. However, the number of years is not balanced for all companies. Based on the sample criteria used in this study, the research sample was 14 Islamic commercial banks for the years 2008-2019.

\section{Operational Definition and Variable Measurement Social Performance}

Social performance is the social responsibility of Islamic banks that differentiates it from conventional banks through contributions in the form of managing zakah, shodaqah, qardul hassan to improve people's welfare (Nugraheni, 2018). Social performance is measured using a social performance ratio that includes contributions to economic development, to society and the social environment, to stakeholders, and to human resource education (Nugraheni, 2018).

Size of the Board of Directors

Every company has a board of directors or a group of executives who are responsible for overseeing the activities of the president and top-level managers of the company. The board of directors is also responsible for conducting surveys of business and company activities. The unit of variable used is the number of people. The formula for measuring the board of directors refers to Ardianto \& Rivandi's research (2018), namely:

Board of Directors Size $=\Sigma$ Directors 
MANAGEMENT SCIENCES

Vol. 12 , No. 1, 2022, E-ISSN: 2225-8329 @ 2022 HRMARS

Gender Diversity of Directors

The gender diversity of the board of directors describes the distribution of men and women who occupy the position of members of the board of directors (Anggraeni et al., 2016). The gender diversity of directors in this study is measured using the proportion of women in the board of directors.

Age of Directors

$$
\text { Gender Diversity }=\frac{\text { Woman Director }}{\text { Total Directors }} \times 100 \%
$$

Age is a fairly dominant determinant of a person's work formation (Zulkarnain \& Mirawati, 2019). Age can be an indicator of a person's experience and wisdom, the longer a person lives, the more professional the experience they have. Increasing age, the wiser the person.

$$
\text { Age of Directors }=\frac{\text { Number of Directors Age }>40 \text { years }}{\text { Total Directors }} \times 100 \%
$$

CEO Duality

CEO duality of directors are calculated using the dummy variable calculation method as researched (Putri \& Deviesa, 2017; Setyawan \& Devie, 2017) with the following measurements:

a. Score 0 , if there are no duality positions between directors and commissioners

b. Score 1, if there are duality positions between directors and commissioners

\section{Analysis Techniques}

This study employs model analysis of the panel data regression, namely fixed effect or random effect regression. In this study, the Hausman test finds which panel data regression model is best appropriate between the fixed effect and the random effect regression.

In this study, one equation model was used to evaluate the hypothesis. Model (1) is used to examine the Board of Directors effect, that is proxied by Directors size, gender diversity, age, and CEO duality towards social performance. The following is the model used to carry out testing in this study:

Model 1. Effect of BoD on Social Performance

SP $=\alpha+\beta_{1}$ BoDSize $+\beta_{2}$ Gender $+\beta_{3}$ Age $+\beta_{4}$ Duality $+\varepsilon_{t}$

\section{Results and Discussion}

Descriptive Statistics

Descriptive statistics may be used to obtain an overview of the main value distribution of the data (mean). The standard deviation number can be considered as an indicator of data dispersion. The smaller standard deviation number suggests that the data are towards the average data value. The descriptive statistics of the variables employed in this research have been shown in Table 1.

The SP variable has a mean value of 0.4537815 . Meanwhile, the Board Size variable has a mean value of 4.264706. On the other hand, the mean value of Board gender diversity is 0.1873775 . Meanwhile, the Board age variable has a mean value of 0.9352241 . On the other hand, the mean value of CEO duality is 0.0367647 . Overall, the descriptive statistics of each variable can be seen in Table 1 below. 
MANAGEMENT SCIENCES

Vol. 12, No. 1, 2022, E-ISSN: 2225-8329 @ 2022 HRMARS

Table 1. Descriptive Statistics Results

\begin{tabular}{lllll}
\hline Variable & Mean & Min & Max & Std. Dev. \\
SP & 0.4537815 & 0 & 0.7714286 & 0.1607262 \\
BoDSize & 4.264706 & 3 & 7 & 0.9830813 \\
Gender & 0.1873775 & 0 & 0.6666667 & 0.1959203 \\
Age & 0.9352241 & 0 & 1 & 0.1908242 \\
Duality & 0.0367647 & 0 & 1 & 0.1888793 \\
\hline
\end{tabular}

Hypothesis Test Results

Table 2. Hypothesis Test Results

\begin{tabular}{lr}
\hline Independent Variable & $\begin{array}{r}\text { Dependent Variable } \\
\text { ROA }\end{array}$ \\
\hline Const & 0.2517252 \\
& $(3.77)^{* * *}$ \\
\hline BoardSize & 0.0381225 \\
& $(2.85)^{* * *}$ \\
\hline Gender & -0.0703395 \\
& $(-0.87)$ \\
\hline Age & 0.0360736 \\
& $(0.84)$ \\
\hline CEODuality & 0.1254986 \\
& $(13.25)^{* * *}$ \\
\hline $\mathbf{R}^{2}$ Within & 0.1072 \\
Wald chi $^{2}$ & 5460.74 \\
Prob $>$ chi $^{2}$ & $0.0000^{* * *}$ \\
\hline Note: ${ }^{* * *}$ significant at $1 \% ;{ }^{* *}$ significant at $5 \%$
\end{tabular}

The Result of Hypothesis 1 Test

Hypothesis 1 testing aims to test whether board size has positive effect towards social performance of Indonesia Islamic Bank. Table 2 showed the results of overall hypothesis testing in this study. The result of hypothesis 1 testing showed that Board of Director size has positive effect towards social performance with a coefficient of 0.0381225 at a $1 \%$ significance level. This indicates that the more member of the board, the monitoring functions of the board will be better and it can lead to social performance improvement. Therefore, hypothesis 1 which stated that there is a positive effect of board size towards social performance, is supported with confidence level of $99 \%$.

Hypothesis 1 testing result prove that the effect of board size towards social performance will lead to higher social performance for the banks. Honi et al. (2020) explains that company must pay more attention to qualities such as competence, skills and professionalism possessed by each board of directors in the company. Jensen \& Meckling (1976) also explained that according to agency theory, a professional board of directors tends to make management monitoring more effective, has the potential, has broader experience and knowledge and provides better advice for company progress and results in higher company performance. So, it can be concluded that the size of the board of directors in a company could affect the social performance of the banks. This is consistent with previous research (Assenga et al., 2018; Dalton et al., 1999; Muchemwa et al., 2016; Palaniappan, 2017; Topal 
MANAGEMENT SCIENCES

Vol. 12 , No. 1, 2022, E-ISSN: 2225-8329 @ 2022 HRMARS

\& Dogan, 2014) which found positive relationship between board size and company performance.

The Result of Hypothesis 2 Test

Hypothesis 2 testing aims to test whether board gender diversity has positive effect towards social performance of Indonesia Islamic Bank. The result of hypothesis 2 testing showed that there is no effect of board gender diversity towards social performance. Therefore, hypothesis 2 which stated that there is a positive effect of board gender diversity towards social performance of Indonesian Islamic Bank, is not supported.

The result of hypothesis 2 is not proved. Women do not like risk compared to men in their decision making, so that even though they are involved in holding a position in a company the percentage is still small compared to men (Lisaime \& Sri, 2018). In this study, although most companies involve women on their board of directors, the number is still small, on average Islamic commercial banks only have one female director out of a total of four directors. These results are in line with research conducted by Lisaime \& Sri (2018); Maghfiroh \& Utomo (2019); Raharjanti (2019) with research results showing that the Gender Diversity of Directors has no effect on Company Performance.

The Result of Hypothesis 3 Test

Hypothesis 3 testing aims to test whether board age has positive effect towards social performance of Indonesia Islamic Bank. The result of hypothesis 3 testing showed that there is no effect of board age towards social performance. Therefore, hypothesis 3 which stated that there is a positive effect of board age towards social performance of Indonesian Islamic Bank, is not supported.

The result of hypothesis 3 is not proved. Age diversity of board does not affect performance. As age difference is likely to lead to variation in personal values (Sun \& Wang, 2010), the research then further decompose age diversity by value diversity. Heterogeneity of directors' value on work, prudence, and wealth may have difference effect on bank's social performance. Research from Amin \& Sunarjanto (2016) found that age of board does not affect performance.

The Result of Hypothesis 4 Test

Hypothesis 4 testing aims to test whether CEO duality of board members has positive effect towards social performance of Indonesia Islamic Bank. The result of hypothesis 4 testing showed that CEO duality has positive effect towards social performance with a coefficient of 0.1254986 at a $1 \%$ significance level. Therefore, hypothesis 4 which stated that there is a positive effect of CEO duality towards social performance, is supported with confidence level of $99 \%$.

Hypothesis 4 testing result prove that the effect of CEO duality towards social performance will lead to higher social performance for the banks. CEO duality positions of directors may lead to performance for the company, because when a director is also a commissioner, the understanding and knowledge of the operational environment in the company is also broad (Chandra \& Devie, 2017).

\section{Conclusions}

This research examines the positive effects of board of directors towards social performance of Islamic banks in Indonesia. Empirical results showed that board of directors' size and CEO 
MANAGEMENT SCIENCES

Vol. 12, No. 1, 2022, E-ISSN: 2225-8329 @ 2022 HRMARS

duality position positively affects social performance. On the other hand, the result failed to prove that board gender and age diversity positively affect social performance of Islamic banks.

\section{References}

Amin, N. N., \& Sunarjanto. (2016). Pengaruh Diversitas Dewan Komisaris dan Dewan Direksi terhadap Kinerja Perusahaan. Fokus Manajerial Jurnal Manajemen Dan Kewirausahaan, 11(3), 51-66. https://jurnal.uns.ac.id/fokus-manajerial/article/view/8430/7584

Anggraeni, G., Kristanti, F. T., \& Muslih, M. (2016). Pengaruh Intelectual Capital, Gender Diversity, Age Diversity, dan Tenure Diversity Terhadap Kinerja Keuangan Perusahaan. EProceeding of Management, 3(2), 1656-1664.

Ardianto, D., \& Rivandi, M. (2018). Pengaruh Enterprise Risk Management Disclosure, Intellectual Capital Disclosure Dan Struktur Pengelolaan Terhadap Nilai Perusahaan. Profita: Komunikasi Ilmiah Akuntansi Dan Perpajakan, 11(2), 284-305. https://doi.org/10.22441/profita.2018.v11.02.009

Assenga, M. P., Aly, D., \& Hussainey, K. (2018). The impact of board characteristics on the financial performance of Tanzanian firms. Corporate Governance, 18(6), 1089-1106. https://doi.org/10.1108/CG-09-2016-0174

Carter, D. A., D'Souza, F., Simkins, B. J., \& Simpson, W. G. (2010). The Gender and Ethnic Diversity of US Boards and Board Committees and Firm Financial Performance. Corporate Governance: An International Review, 18(5), 396-414. https://doi.org/10.1111/j.14678683.2010.00809.x

Carter, D. A., Simkins, B. J., \& Simpson, W. G. (2003). Corporate Governance, Board Diversity, and Firm Value. The Financial Review, 38, 33-53. https://doi.org/10.1103/PhysRevD.97.115021

Chandra, K., \& Devie. (2017). Pengaruh CEO Duality. Business Accounting Review, 5(1), 301312.

Dalton, D. R., Daily, C. M., Johnson, J. L., \& Ellstrand, A. E. (1999). Number of Directors and Financial Performance: A Meta-Analysis. Academy of Management Journal, 42(6), 674686.

Fama, E. F., \& Jensen, M. C. (1983). Separation of Ownership and Control. Journal of Law and Economic, 26(2), 301-325.

Ferris, S. P., Jagannathan, M., \& Pritchard, A. C. (2003). Too Busy to Mind the Business? Monitoring by Directors with Multiple Board Appointments. Journal of Finance, 58(3), 1087-1112. https://doi.org/10.1111/1540-6261.00559

Hambrick, D. C., \& Mason, P. A. (1984). Upper Echelons: The Organization as a Reflection of Its Top Managers. Academy of Management Review, 9(2), 193-206. https://doi.org/10.5465/amr.1984.4277628

Haniffa, R., \& Hudaib, M. (2007). Exploring the Ethical Identity of Islamic Banks via Communication in Annual Reports. Journal of Business Ethics, 76(1), 97-116.

https://doi.org/10.1007/s10551-006-9272-5

Hassan, R., \& Marimuthu, M. (2016). Corporate Governance, Board Diversity, and Firm Value: Examining Large Companies Using Panel Data Approach. Economics Bulletin, 36(3), 1737-1750.

Hermalin, B. E., \& Weisbach, M. S. (2003). Boards of Directors as Endogenously Determined Institutions: A Survey of the Economy Literature, Economy Policy Review. FRBNY Economic Policy Review, April, 7-26. 
MANAGEMENT SCIENCES

Vol. 12, No. 1, 2022, E-ISSN: 2225-8329 ๔ 2022 HRMARS

Honi, H. Y., Saerang, I. S., \& Tulung, J. E. (2020). Pengaruh Good Corporate Governance Terhadap Kinerja Keuangan Bank Umum Konvensional Tahun 2014-2018. Jurnal EMBA: Jurnal Riset Ekonomi, Manajemen, Bisnis Dan Akuntansi, 8(3), 296-305.

Innayah, M. N., Pratama, B. C., \& Hanafi, M. M. (2020). The Effect of Intellectual Capital towards Firm Performance and Risk with Board Diversity as a Moderating Variable: Study in ASEAN Banking Firms. Jurnal Dinamika Manajemen, 11(1), 27-38. https://doi.org/10.15294/jdm.v11i1.21487

Innayah, M. N., Pratama, B. C., \& Tubastuvi, N. (2021). Board Diversity and Its Effects on Firm Performance and Risk: A Study in Banking Firms in Indonesia. Journal of Accounting and Investment, 22(1), 206-220. https://doi.org/10.18196/jai.v22i1.10005

Jensen, M. C. (1993). The Modern Industrial Revolution, Exit, and the Failure of Internal Control Systems. The Journal of Finance, 48(3), 831-880.

https://doi.org/10.1111/j.1540-6261.1993.tb04022.x

Jensen, M. C., \& Meckling, W. H. (1976). Theory of The Firm: Managerial Behavior, Agency Costs and Ownership Structure. Journal of Financial Economics, 3, 305-360.

Lipton, M., \& Lorsch, J. W. (1992). A Modest Proposal for Improved Corporate Governance. Business Lawyer, 48(1), 59-77.

http://web.a.ebscohost.com.eserv.uum.edu.my/bsi/detail?vid=19\&sid=e3a1315cd940-4744-b224-

1ce498b43ead@sessionmgr4005\&hid=4114\&bdata=JnNpdGU9YnNpLWxpdmU=\#db=b th\&AN=5963897

Lisaime, \& Sri, D. (2018). Analisis Pengaruh Diversitas Gender, Kepemilikan Institusional, dan Ukuran Perusahaan Terhadap Kinerja Keuangan. Jurnal Keuangan Dan Bisnis, 16(1), 6483.

Maghfiroh, V. D., \& Utomo, D. C. (2019). Pengaruh Diversitas Gender pada Struktur Dewan terhadap Kinerja Keuangan Perusahaan. Diponegoro Journal of Accounting, 8(3), 1-9.

Muchemwa, M. R., Padia, N., \& Callaghan, C. W. (2016). Board composition, board size and financial performance of Johannesburg stock exchange companies. South African Journal of Economic and Management Sciences, 19(4), 497-513.

https://doi.org/10.4102/sajems.v19i4.1342

Ntim, C. G. (2015). Board diversity and organizational valuation: unravelling the effects of ethnicity and gender. Journal of Management and Governance, 19(1), 167-195. https://doi.org/10.1007/s10997-013-9283-4

Nugraheni, P. (2018). Sharia Supervisory Board and Social Performance of Indonesian Islamic Banks. Jurnal Akuntansi Dan Auditing Indonesia, 22(2), 137-147.

https://doi.org/10.20885/jaai.vol22.iss2.art6

Palaniappan, G. (2017). Determinants of corporate financial performance relating to board characteristics of corporate governance in Indian manufacturing industry: An empirical study. European Journal of Management and Business Economics, 26(1), 67-85. https://doi.org/10.1108/EJMBE-07-2017-005

Putri, L. L., \& Deviesa, D. (2017). Pengaruh CEO Duality Terhadap Financial Performance Dengan Earnings Management Sebagai Variabel Intervening. Business Accounting Review, 5(1), 169-180.

Raharjanti, R. R. (2019). Gender Diversity, Struktur Kepemilikan, dan Kinerja Perusahaan: Studi Pada Perusahaan Perbankan di Indonesia. Jurnal Aktual Akuntansi Keuangan Bisnis Terapan, 2(2), 133-142. https://doi.org/10.32497/akunbisnis.v2i2.1659

Rompis, N. K., Worang, F. G., \& Tulung, J. E. (2018). Pengaruh Ukuran Dewan, Keberagaman 
Usia dan Keberagaman Gender Terhadap Kinerja Keuangan Bank Pembangunan Daerah di Seluruh Indonesia Buku 2 Tahun 2014-2016. Jurnal EMBA: Jurnal Riset Ekonomi, Manajemen, Bisnis Dan Akuntansi, 6(4), 2628-2637.

https://doi.org/10.35794/emba.v6i4.21037

Rumapea, M. (2017). Pengaruh Good Corporate Governance Terhadap Profitabilitas Perusahaan (Studi pada Perusahaan Manufaktur yang Terdaftar di Bursa Efek Indonesia Tahun 2013-2015). Jurnal Akuntansi Dan Keuangan Methodist, 1(1), 45-56. repository.unej.ac.id/bitstream/handle/123456789/.../SHERLY

HERIYANTO.pdf?...\%0A\%0A

Setyawan, A. M., \& Devie. (2017). Pengaruh CEO Duality Terhadap Firm Value Dengan Financial Performance Sebagai Variabel Intervening. Business Accounting Review, 4(1), 325-336.

Shukeri, S. N., Shin, O. W., \& Shaari, M. S. (2012). Does Board of Director's Characteristics Affect Firm Performance? Evidence from Malaysian Public Listed Companies. International Business Research, 5(9), 120-127. https://doi.org/10.5539/ibr.v5n9p120

Sun, J., \& Wang, X. (2010). Value differences between generations in China: A study in Shanghai. Journal of Youth Studies, 13(1), 65-81.

https://doi.org/10.1080/13676260903173462

Topal, Y., \& Dogan, M. (2014). Impact of Board Size on Financial Performance: The Case of BIST Manufacturing Industry. International Journal of Business Management and Economic Research (IJBMER), 5(4), 74-79.

Wijethilake, C., Perera, A., \& Sujatha, E. (2015). Board involvement in corporate performance: evidence from a developing country. Journal of Accounting in Emerging Economies, 5(3), 250-268.

Zulkarnain, \& Mirawati, W. (2019). Karakteristik Dewan Direksi dan Pengaruhnya terhadap Kinerja Keuangan Perusahaan. Cakrawala, 2(2), 72-81.

http://cakrawala.imwi.ac.id/index.php/cakrawala/article/view/31 